\title{
Identifikasi Pembentukan Identitas Orientasi Seksual Pada Homoseksual (Gay)
}

\section{Identification of Sexual Orientation Identity Formation in Homosexuals (Gay)}

\author{
Eriyanti Novita* \\ Fakultas Psikologi, Universtias Medan Area, Indonesia \\ Disubmit: 29 Maret 2021; Diproses: 29 Maret 2021; Diaccept: 15 Agustus 2021; Dipublish: 15 Agustus 2021 \\ *Corresponding author: E-mail: eriyanti@staff.uma.ac.id
}

\begin{abstract}
Abstrak
Penelitian ini hendak mengetahui bagaimana proses seseorang yang memiliki orientasi seksual dan membentuk identitas dirinya. Secara lebih rinci ingin mengatahui bagaimana dia mampu mendefenisikan diri sebagai seorang homoseksual (gay) ditengah kuasa wacana heteroseksual yang ada di masyarakat. Penelitian ini bersifat penelitian deskriptif koralasional dengan pendekatan kuantitatif. Pendekatan yang digunakan adalah fenomenologi. Peneliti memandang bahwa untuk mendapatkan pemahaman yang komprehensif tentang kehidupan gay, fenomenologi adalah pendekatan yang tepat sebab disana peneliti dituntut untuk lebih dalam ketika mendekati dan menyelami kehidupan subjek. Berdasarkan hasil perhitungan terhadap 35 subjek pada laki-laki homoseksual terhadap pembentukan identitas orientasi seksual, terdapat empat faktor yang memiliki kontribusi. Keempat faktor tersebut adalah keluarga, pergaulan dan lingkungan, akhlak dan morak, serta pengetahuan agama yang lemah. Sedangkan hasil analisis diketahui bahwa dari keempat faktor tersebut, faktor yang memiliki kontribusi tertinggi dalam pembentukan identitas orientasi seksual pada homoseksual yang ada di cafe holliwings adalah faktor keluarga yaitu sebesar 27 persen. Lebih rinci lagi dijelaskan bahwa dari total 35 subjek sebanyak 7 orang berada pada kategori tinggi (20 persen), 18 orang berkategori sedang (51 persen), dan 10 orang berkategori rendah ( 29 persen).
\end{abstract}

Kata Kunci : Pembentukan Identitas Oreintasi Seksual

\begin{abstract}
This study aims to find out how the process of someone who has a sexual orientation and forms his identity. In more detail, I want to know how he is able to define himself as a homosexual (gay) in the midst of the power of heterosexual discourse in society. This research is a descriptive correlational research with a quantitative approach. The approach used is phenomenology. The researcher views that to get a comprehensive understanding of gay life, phenomenology is the right approach because there researchers are required to go deeper when approaching and exploring the life of the subject. Based on the calculation of 35 subjects in homosexual men to the formation of sexual orientation identity, there are four factors that have a contribution. The four factors are family, association and environment, morals and morals, and weak religious knowledge. While the results of the analysis show that of the four factors, the factor that has the highest contribution to the formation of sexual orientation identity in homosexuals in cafe holliwings is the family factor, which is 27 percent. In more detail, it was explained that from a total of 35 subjects, 7 people were in the high category (20 percent), 18 people were in the medium category (51 percent), and 10 people were in the low category (29 percent).

Keywords: Formation of Sexual Orientation Identity
\end{abstract}

DOI: https://doi.org/10.51849/j-p3k.v2i2.99

Rekomendasi mensitasi :

Novita, E. (2021), Identifikasi Pembentukan Identitas Orientasi Seksual Pada Homoseksual (Gay). Jurnal Penelitian Pendidikan, Psikologi dan Kesehatan (J-P3K), 2 (2): 194-205. 


\section{PENDAHULUAN}

Setiap manusia diciptakan oleh Allah SWT berpasang-pasangan, yang terdiri dari laki laki dan perempuan, mereka diciptakan untuk membangun sebuah rumah tangga, kemudian menghasilkan keturunan. Keturunan dapat dihasilkan jika ada perkawinan beda jenis, jika tidak maka tidak ada keturunan yang dihasilkan. Penelitian ini tidak membicarakan bagaimana menghasilkan keturunan. Tetapi membahas tentang penghambat dari keberlangsungan generasi keturunan dimasa yang akandatang dikarenakan dari kesalahan orientasi seksual.

Orientasi seksual merupakan perasaan ketertarikan secara seksual dan emosional dengan orang lain. Homoseksual merupakan ketertarikan seksual yang terjadi antara sesama jenis kelamin. Orientasi seksual ini dapat diikuti dengan adanya perilaku seksual atau tidak. Misalnya seseorang laki-laki yang tertarik dengan sejenis namun selama hidupnya dia belum pernah melakukan perilaku seksual dengan laki-laki, maka ia tetap dikatakan memiliki orientasi seksual sejenis. Menurut Swara Srikandi Indonesia dalam (Dermartoto, 2013).

Homoseksualitas bukan sebuah penyakit gangguan jiwa namun identitas seksual ini berlangsung secara terusmenerus serta berkelanjutan. Sehingga potensi penyimpangan seksual menjadi lebih besar. Penyimpangan seksual tersebut acap kali ditandai dengan adanya rasa ketertarikan pada sesama jenis (lakilaki) dan bukan lawan jenis (perempuan). Secara umum identitas seksual yang berkembang dalam masyarakat mengacu pada identitas heteroseksual, yaitu rasa ketertarikan terhadap individu yang berlawan jenis dengan atau tanpa disertai hubungan fisik. Identitas sebagai homoseksual sejak dahulu bahkan dewasa ini telah berkembang dan kian menunjukkan eksistensinya. Identitas ini mengundang berbagai reaksi dalam masyarakat, baik penolakan dan penerimaan, namun diatas itu semua menjadi target bullying atau dikeluarkan dari rumah mereka karena orang tuanya tidak dapat menerima kenyataan bahwa anak mereka adalah seorang gay.

Dalam American Psychological Association (2008) menyebutkan bahwa istilah orientasi juga merujuk pada perasaan seseorang terhadap identitas pribadi dan sosial berdasarkan ketertarikan, perilaku pengungkapannya, dan keanggotaan pada komunitas yang sama. Hingga saat ini penyebab terjadinya orientasi seksual ini belum dapat dipastikan secara pasti. Tetapi prevalensi homoseksual mengalami peningkatan dari tahun ke tahun.

Di dalam kehidupan terdapat sekelompok orang yang memiliki orientasi seksual berbeda. Orientasi seksual menjadi tiga bagian (Supratiknya, 1995), yaitu:1. Heteroseksual, yaitu ketertarikan secara seksual pada jenis kelamin yang berbeda, perempuan tertarik pada lakilaki, dan laki-laki tertarik pada perempuan. 2. Biseksual, ketertarik secara seksual pada perempuan dan laki-laki sekaligus. 3.Homoseksual, yaitu ketertarikan secara seksual pada jenis kelamin yang sama, perempuan tertarik pada perempuan yang disebut sebagai lesbian, dan laki-laki yang tertarik pada laki-laki disebut sebagai gay 
Orientasi seksual sebenarnya merupakan keinginan mendasar dari indvidu untuk memenuhi kebutuhan akan cinta, berhubungan dengan kedekatan atau rasa intim. Bisa jadi akan berkembang sehingga terjadilah sebuah ikatan antara dua insan dalam (Sinyo, 2014). Orientasi seksual juga merupakan salah satu dari empat komponen seksualitas yang terdiri dari daya tarik emosional, romantis, seksual dan kasih sayang dalam diri seseorang dalam jenis kelamin tertentu. Tiga komponen seksualitas adalah jenis kelamin biologis, identitas gender (artinya psikologis pria dan wanita) dan peranan jenis kelamin (norma-norma budaya untuk perilaku feminin dan maskulin). Orientasi seksual berbeda dengan perilaku seksual karena berkaitan dengan perasaan dan konsep diri, namun dapat pula seseorang menunjukkan orientasi seksualnya dalam perilaku mereka dalam (Dermartoto, 2013).

Orientasi seksual terbagi kedalam beberapa golongan, yang pertama homoseksual, yang kedua adalah heteroseksual, dan yang ketiga adalah biseksual. Orientasi seksual yang lazim di masyarakat adalah heteroseksual. Akan tetapi kita tidak bisa menutup mata bahwa ada pula yang memiliki orientasi seksual yang berbeda, misalnya homoseksual. Homoseksual menggambarkan laki-laki atau perempuan yang cenderung menyukai sesama jenisnya. Homoseksual bukan hanya kontak seksual antara seseorang dengan orang lain dari jenis kelamin yang sama tetapi juga menyangkut individu yang memiliki kecendrungan psikologis, emosional, dan sosial terhadap seseorang dengan jenis kelamin yang sama.

Berdasarkan teori perkembangan psikososial Erikson, masa dewasa awal (young adulthood) ditandai dengan adanya kecenderungan intimacy versus isolation. Kalau pada masa sebelumnya, individu memiliki ikatan yang kuat dengan kelompok sebaya, namun pada masa ini ikatan kelompok sudah mulai longgar. Mereka sudah mulai selektif dan membina hubungan yang intim hanya dengan orang-orang tertentu yang sepaham. Jadi pada tahap ini timbul dorongan untuk membentuk hubungan yang intim dengan orang-orang tertentu, dan kurang akrab atau renggang dengan yang lainnya.

Individu dewasa awal atau dewasa dini mencari keintiman emosional dan fisik kepada pasangan romantis. Hubungan ini mensyaratkan keterampilan seperti kesadaran diri, empati, kemampuan mengkomunikasikan emosi, pembuatan keputusan seksual, penyelesaian konflik dan kemampuan mempertahankan komitmen.

Keterampilan tersebut sangat penting ketika individu dewasa awal atau dewasa dini memutuskan untuk menikah, membentuk pasangan yang tidak terikat pernikahan, atau hidup seorang diri, atau memiliki atau tidak memiliki anak dalam (Papalia, 2008). Namun menjadi suatu hal yang tidak lazim ketika pernikahan itu terjadi antara sesama jenis yaitu wanita dengan wanita atau pria dengan pria. Pernikahan sesama jenis tentu menjadi hal yang kontroversial karena menikahi orang yang berjenis kelamin sama dan ikatan ini di golangkan pada hubungan homoseksual. 
Menurut beberapa teori, orientasi seksual merupakan pengaruh murni biologis seperti faktor genetik, hormon prenatal, atau ketidak seimbangan hormon. Dan faktor seseorang manjadi gay salah satunya adalah Menurut Hendra Irawan adalah Pola asuh orang tua sangat berpengaruh terhadap perkembangan seorang anak dalam (H. Irawan, 2016). Menurut sarwono Peritiwa traumatik bisa berdampak terhadap seseorang untuk menjadi seorang gay, Pengaruh lingkungan begitu kuat dalam pembentukan karakter seseorang (Sarwono, 2009). Menurut kelly dan kalat dalam (Kalat, 2007) teori Biologis (genetik) Ada fakta yang ditemukan bahwa faktor genetik menyebabkan seseorang menjadi homoseks.

Adapun ciri-ciri yang membantu mereka untuk mengenali dan dikenali sesama gay dan di dalam masyarakat. Ciriciri tersebut terkadang sengaja dibentuk oleh mereka, tapi ada juga yang dilakukan secara tidak sengaja atau pembawaan secara naluri. Gay lebih menyukai mengenakan pakaian ketat, karena dapat memperlihatkan lekuk tubuh si pemakai. Bagi gay, lekukan tubuh merupakan daya jual tersendiri. Gay lebih senang memakai warna mencolok. Dalam berkomunikasi gaya bicaranya pun lebih feminim dan perhiasan yang dikenakannya pun cenderung "ramai". Bahkan itu merupakan alat komunikasi sesama gay. Ciri lainnya adalah selalu tertarik pada aktivitas yang biasanya dilakukan wanita.

Okdinata mengatakan, Fenomena gay dalam pandangan masyarakat secara umum ditanggapi secara beragam. Secara garis besar pandangan tersebut terbagi dalam empat kelompok dalam (A.
Irawan, 2015) yaitu kelompok pertama (normative) yang berpandangan bahwa gay adalah kehidupan yang tidak sesuai dengan norma agama, sosial dan merupakan perilaku yang tidak normal, kelompok ke dua (inclusive) yang menerima keberadaan kaum gay dengan konsekuensi kaum tersebut tidak mengganggu kehidupan masyarakat di sekitarnya; kelompok ketiga (legal oriented people) yang menyatakan bahwa pilihan kehidupan sebagai gay adalah bagian dari Hak Asasi Manusia (HAM) yang hakiki, kelompok empat (Conservative people) yang berpandangan bahwa kehidupan gay adalah sumber penularan berbagai penyakit khususnya penyakit kelamin.

Perbedaan stigma masyarakat yang ada sekarang dalam menilai keberadaan kaum gay sangat beragam. Suatu perspektif bahwa keberadaan kaum gay bukanlah suatu masalah dan bukanlah pengganggu bagi kehidupan mereka patut diapresiasi. Namun demikian, bukan berarti masyarakat yang menolak keberadaan mereka harus dianggap suatu pelanggaran sosial. Hal ini karena masyarakat memiliki keyakinan tertentu yang harus melarang keberadaan mereka hidup dilingkungan sekitar.

Saat ini dapat dipastikan sudah banyak orang yang memiliki orientasi homoseksual. Menurut Wakil Gubernur Sumatera Barat Nasrul Abit dalam Tribunnews.com selasa 7 mei 2019 prilaku lesbian, gay, biseksual dan transgender atau LGBT di indonesia makin meresahkan. Ini karena populasi orang dengan perilaku menyimpang ini yang diduga semakin banyak di indonesia. Jumlah atau populasi pelaku LGBT 
terbanyak di indonesia berada di Sumatera Barat dan disebut mencapai 18.000 orang. Nasrul mengatakan, jumlah lesbian, gay, biseksual dan transgender (LGBT) di Sumbar saat ini merupakan yang terbanyak di Indonesia.

Dikarenakan pada data statistik jumlah gay yang semakin banyak yaitu mencapai 18000 orang dan kemudian di tambah lagi dengan banyak publik figur yang serimg muncul di TV dan eksis di berbagai sosial media, dan karena di jaman sekarang ini juga norma-norma yang telah tergeser. Dan di ligkungan keluarga juga sangat mempengaruhi yang di mana peran orang tua yang kurang ikut andil dalam memberikan pemahaman seks atau sex education kepada anaknya, maka hal inilah yang menyebabkan mereka mencari figur di luar rumah, yang dimana figur ini mendorong mereka untuk berprilaku menyimpang dan mengakibatkan penyimpangan orentasi seksual. Hal ini sesuai dengan teori sigmund freud, yang dimana menurutnya, salah satu alasan yang membuat anakanak menyelesaikan konflik oedipus adalah untuk menghilangkan ketakutan kehilangan cinta orang tua dan dihukum karena memiliki harapan-harapan seksual yang tidak diinginkan terhadap orang tua dari jenis kelamin yang berbeda dalam (Santrock, 2007).

Dengan menggunakan media sosial seorang gay merasa aman akan identitas dirinya, mereka bisa menggunakan media sosial yang biasa digunakan orang-orang pada umumnya, seperti instagram, facebook, bahkan mereka juga menggunakan media sosial yang dikhususkan untuk para gay mencari pasangan seperti hornet, blued, grinder dalam (Hadley \& Erianjoni, 2019).

Hasil diatas menunjukkan bahwa banyak faktor yang dapat mempengaruhi pembentukan identitas orientasi seksual, diantaranya yaitu pola asuh orang tua, faktor lingkungan, dan yang terakhir faktor genetik. Menurut Irawan Pengaruh lingkungan begitu kuat dalam pembentukan karakter seseorang, hal ini juga berlaku dalam pembentukan orientasi seksual. faktor lingkungan menjadi faktor pendukung mereka menjadi gay dalam (H. Irawan, 2016).

Berdasarkan pendapat di atas, maka dapat di simpulkan bahwa faktor lingkungan sangat berpengaruh terhadap pembentukan identitas orientasi seseorang. Dukungan dari lingkungan merupakan salah satu bentuk dukungan emosional, yang akan sangat membantu seseorang dalam menghadapi masalah. Bentuk dukungan mereka berupa perhatian, empati, kepedulian dan kasih sayang.

Fenomena diatas membuat peneliti tertarik untuk melakukan penelitian dengan judul "Identifikasi Pembentukan Identitas Orientasi Seksual pada Homoseksual (Gay)". Penelitian ini bertujuan untuk mengetahui apa yang membentuk identitas orientasi seksual pada homoseksual (gay).

Fokus dalam penelitian ini adalah: (a) Mengenai hal-hal apa saja yang dapat membentuk identitas orientasi seksual pada homoseksual (gay) di kota Medan. (b) Fenomena yang marak terjadi di kelompok homoseksual di kota medan dan dari segi lingkungan peneliti yang memiliki banyak teman yang homoseksual (gay). 


\section{METODE PENELITIAN}

Penelitian ini berlokasi di Cafe Holliwings dan sebagai Objek teliti adalah komunitas homoseksual yang ada di café tersebut. Komunitas ini memiliki kurang lebih 35 anggota yang terdiri dari laki-laki dewasa, yang memiliki latar belakang yang berbeda, pekerjaan yang berbeda, suku bangsa yang berbeda dan usia mereka juga berbeda pula di mulai dari usia 22 tahun sampai dengan 35 tahun. Adapun yang menjadi subjek penelitian ini adalah seluruh anggota komunitas homoseksual yang sering berkumpul di Café Holliwings.

Penelitian ini bersifat penelitian deskriptif korelasional dengan pendekatan kuantitatif. Metode deskriptif merupakan suatu pencarian fakta menggunakan interprestasi yang tepat. Penelitian ini dilaksanakan dengan desain penelitin survei, yaitu mengambil contoh dari suatu populasi dan menggunakan kuesioner sebagai alat pengumpulan data yang pokok (Singarimbun \& Effendi, 2008). Variabel penelitian yang akan dikaji dalam penelitian ini adalah satu variabel yaitu Identitas Orientasi Seksual.

\section{HASIL DAN PEMBAHASAN}

Teknik analisi data yang digunakan dalam penelitian ini adalah analisis deskriptif dan analisis faktor satu variabel yaitu Identitas Orientasi Seksual. Sebelum data dianalisis, terlebih dahulu dilakukan uji asumsi terhadap variabel identitas Orientasi seksual yang terdiri dari uji normalitas dan uji homogenitas. Pengujian asumsi dan analisis data ini menggunakan bantuan program komputer yaitu IBM SPSS 21.
1. Hasil analisis data faktor pembentukan identitas orientasi seksual, a. Klasifikasi faktor faktor yang mempengaruhi pembentukan identitas orientasi seksual

Tabel 1 Persentase Faktor-Faktor.

\begin{tabular}{cc}
\hline $\begin{array}{c}\text { Faktor } \\
\text { Pembentukan }\end{array}$ & Presentase \\
\hline Faktor & $893 / 3253 \times 100 \%=27,45$ \\
Keluarga & \\
Faktor & $859 / 3253 \times 100 \%=26,41$ \\
Liingkungan & \\
Faktor Moral & $798 / 3253 \times 100 \%=24,53$ \\
Faktor Agama & $703 / 3253 \times 100 \%=21,61$ \\
\hline
\end{tabular}

Berdasarkan perhitungan table di atas, maka diketahui bahwa pembantukan identitas orientasi seksual pada homoseksual dari 35 subjek, dinyatakan bahwa diurutan pertama penyebab pembentukan identitas orientasi seksual berada di faktor keluarga yaitu sebesar 27 persen. Kemudian diurutan kedua penyebab pembentukan identitas orientasi seksual berada di faktor lingkunganyaitu sebesar 26 persen. Sementara untuk urutan ketiga penyebab pembentukan identitas orientasi seksual berada di faktor akhlak dan moral yaitu sebesar 25 persen. Dan diurutan ke empat terdapat faktor agama yaitu sebesar 22 pesen penyebab pembentukan identitas orientasi seksual yang terjadi pada komunitas homoseksual yang ada di cafe holliwings.

b. Faktor keluarga

Tabel2 Hasil Analisis untuk Faktor Keluarga.

\begin{tabular}{|c|c|c|}
\hline \multicolumn{3}{|c|}{ Faktor keluarga } \\
\hline Kategori & Frekuensi & Presentase \\
\hline Rendah & 10 & $29 \%$ \\
\hline Sedamg & 18 & $51 \%$ \\
\hline Tinggi & 7 & $20 \%$ \\
\hline Total & 35 & $100 \%$ \\
\hline
\end{tabular}

persenberdasarkan tabel diatas dapat dilihat bahwa dari 35 orang sampel penelitian sebesar 29 persen menyatakan 
bahwa faktor keluarga berkontribusi rendah dalam mempengaruhi pembentukan identitas orientasi seksual. Kemudian sebesar 51 persen menyatakan bahwa faktor keluarga cukup mempengaruhi pembentukan identitas orientasi seksual. Dan sebesar 20 persen menyatakan faktor keluarga sangat tinggi mempengaruhi pembentukan identitas orientasi seksual.

c. Faktor orang tua

Tabel 3 Hasil Analisis untuk Faktor Pergaulan dan lingkungan.

\begin{tabular}{ccc}
\hline \multicolumn{3}{c}{ Faktor lingkungan } \\
\hline Kategori & Frekuensi & Presentase \\
\hline Rendah & 5 & $14 \%$ \\
Sedamg & 22 & $63 \%$ \\
Tinggi & 8 & $23 \%$ \\
Total & 35 & $100 \%$ \\
\hline
\end{tabular}

Jika dilihat dari bentuk

persenberdasarkan tabel diatas dapat dilihat bahwa dari 35 orang sampel penelitian subjek penelitian sebesar 14 persen menyatakan bahwa faktor pergaulan dan lingkungan berkontribusi rendah dalam mempengaruhi pembentukan identitas orientasi seksual. Kemudian sebesar 63 persen menyatakan bahwa faktor lingkungan berkontribusi sedang atau cukup mempengaruhi pembentukan identitas orientasi seksual. Dan sebesar 23 persen menyatakan bahwa faktor lingkungan berkontribusi tinggi dalam mempengaruhi pembentukan identitas orientasi seksual pada seseorang.

d. Faktor akhlak dan moral

Tabel 4 Hasil Analisis untuk Faktor Akhlak dan Moral

\begin{tabular}{ccc}
\hline \multicolumn{3}{c}{$\begin{array}{c}\text { Faktor akhlak dan } \\
\text { moral }\end{array}$} \\
\hline Kategori & Frekuensi & Presentase \\
\hline Rendah & 6 & $17 \%$ \\
Sedamg & 21 & $60 \%$ \\
Tinggi & 8 & $23 \%$ \\
Total & 35 & $100 \%$ \\
\hline
\end{tabular}

Jika dilihat dari bentuk persenberdasarkan tabel diatas dapat dilihat bahwa dari 35 orang sampel penelitian subjek penelitian sebesar 17 persen menyatakan bahwa faktor akhlak dan moral berkontribusi rendah dalam mempengaruhi pembentukan identitas orientasi seksual. Kemudian sebesar 60 persen menyatakan bahwa faktor akhlak dan moral berkontribusi sedang atau cukup mempengaruhi pembentukan identitas oktrientasi seksual mereka. Dan sebesar 23 persen menyatakan bahwa faktor akhlak dan moral berkontribusi tinggi dalam mempengaruhi pembentukan identitas orientasi seksual pada seseorang.

\section{e. Faktor agama}

Tabel 5 Hasil Analisis untuk Faktor Agama.

\begin{tabular}{|c|c|c|}
\hline \multicolumn{3}{|c|}{ Faktor Agama } \\
\hline Kategori & Frekuensi & Presentase \\
\hline Rendah & 7 & $20 \%$ \\
\hline Sedamg & 19 & $54 \%$ \\
\hline Tinggi & 9 & $26 \%$ \\
\hline Total & 35 & $100 \%$ \\
\hline
\end{tabular}

persenberdasarkan tabel diatas dapat dilihat bahwa dari 35 orang sampel penelitian subjek penelitian sebesar 20 persen menyatakan bahwa faktor agama berkontribusi rendah dalam mempengaruhi pembentukan identitas orientasi seksual. Kemudian sebesar 54 persen menyatakan bahwa faktor agama berkontribusi sedang atau cukup mempengaruhi pembentukan identitas orientasi seksual mereka. Dan sebesar 26 persen menyatakan bahwa faktor agama berkontribusi tinggi mempengaruhi pembentukan identitas orientasi seksual mereka. 
f. Faktor usia

Tabel 6 Hasil Analisis untuk Faktor Usia.

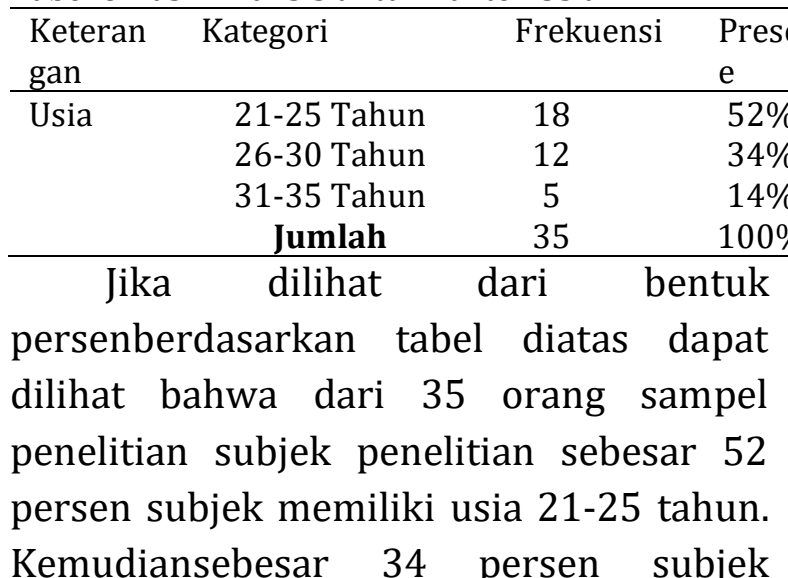

berusia 26-30 tahun. Dan sebesar 14 persen subjek penelitian berusia 31-35 tahun.

g. Faktor pendidikan

Tabel 7 Hasil Analisis untuk Faktor Pendidikan.

\begin{tabular}{cccc}
\hline Keterangan & Kategori & Frekuensi & Presentase \\
\hline Pendidikan & SMA & 12 & $34 \%$ \\
& D3 & 1 & $3 \%$ \\
& S1 & 22 & $63 \%$ \\
& Jumlah & 35 & $100 \%$
\end{tabular}

Jika dilihat dari bentuk persen

berdasarkan tabel diatas dapat dilihat bahwa dari 35 orang sampel penelitian yang telah diberikan angket subjek penelitian terdapat sebesar 34 persen subjek yang memiliki pendidikan terakhir yaitu Sekolam menengah pertama atau SMA. Kemudian sebesar 3 persen subjek yang memiliki pendidikan terakhit yaitu lulusan D3, dan yang terakhir adalah sebesar 63 persen subjek penelitian yang memiliki berpendidikan terakhir yaitu S1. h. Faktor Pekerjaan

Tabel 8 Hasil Analisis untuk Faktor Pekerjaan.

Kategori Frekuen Presenta

\begin{tabular}{|c|c|c|c|}
\hline & & si & se \\
\hline \multirow[t]{7}{*}{ Pekerjaan } & $\begin{array}{c}\text { Karyawan } \\
\text { Swasta }\end{array}$ & 13 & $37 \%$ \\
\hline & $\begin{array}{c}\text { Wirausah } \\
\mathrm{a}\end{array}$ & 4 & $11 \%$ \\
\hline & Marketing & 9 & $26 \%$ \\
\hline & $\begin{array}{c}\text { Reseptioni } \\
\mathrm{S}\end{array}$ & 2 & $6 \%$ \\
\hline & SPV & 2 & $6 \%$ \\
\hline & $\begin{array}{l}\text { Asisten } \\
\text { Manager }\end{array}$ & 4 & $11 \%$ \\
\hline & $\begin{array}{l}\text { Dokter } \\
\text { Total }\end{array}$ & $\begin{array}{c}1 \\
35\end{array}$ & $\begin{array}{c}3 \% \\
100 \%\end{array}$ \\
\hline
\end{tabular}

Berdasarkan tabel diatas dapat dilihat bahwa dari 35 orang sampel penelitian yang telah diberikan angket, maka dapt dilihat bahwa terdapat sebanyak 13 orang subjek penelitian berasal dari seorang karyawan swasta. Kemudian sebanyak 4 orang subjek penelitian adalah sebagai seorang $\%$ wirausaha, lalu sebanyak 9 orang subjek penelitian adalah sebagai seorang Marketing, ada juga sebanyak 2 orang subjek penelitian bekerja sebagai seorang reseptionis, dan sebanyak 2 orang subjek penelitian bekerja sebagai seorang Superviser (SPV), Dan sebanyak 4 orang subjek penelitian yang bekerja sebagai seorang asistem manager dan terakhir sebanyak 1 orang subjek penelitian yang bekerja sebagai seorang dokter.

Jika dilihat dari bentuk persenberdasarkan tabel diatas dapat dilihat bahwa dari 35 orang sampel penelitian yang telah diberikan angket subjek penelitian sebesar 37 persen subjek penelitian bekerja sebagai seorang karyawan swasta di suatu perusahaan. Kemudian sebesar 11 persen subjek penelitian yang lebih memilih untuk tidak bekerja dengan orang lain akan tetapi mereka lebih memilih sebagai 
seorangwirausaha. Sebesar 26 persen subjek penelitian berasal dari seorang Marketing. Sebesar 6 persen subjek penelitian berasal dari reseptionis. Sebesar 6 persen subjek penelitian berasal dari seorang SPV. Sebesar 11 persen subjek penelitian yang berasal dari seorang asistem manager dan sebesar 3 persen subjek penelitian berasal dari seorang dokter.

i. Faktor relationship

Tabel 9 Hasil Analisis untuk Faktor Relatiionship.

\begin{tabular}{lccc}
\hline Keterangan & Kategori & Frekuensi & Presentase \\
\hline Status & Lajang & 24 & $69 \%$ \\
& Berpaca & 11 & $31 \%$ \\
& ran & & \\
& Jumlah & 35 & $100 \%$ \\
\hline
\end{tabular}

Berdasarkan tabel diatas dapat dilihat bahwa dari 35 orang sampel penelitian, sebanyak 24 orang subjek penelitian lebih ingin untuk tidak memiliki hubungan atau lajang. Kemudian sebanyak 11 orang subjek penelitian memilih untuk memiliki hubungan atau berpacaran.

Jika dilihat dari bentuk persenberdasarkan tabel diatas dapat dilihat bahwa dari 35 orang sampel penelitian subjek penelitian sebesar 69 persen subjek penelitian lebih ingin untuktidak memiliki hubungan atau lajang. Kemudian sebesar 31 persen subjek penelitian memilih untuk memiliki hubungan atau berpacaran.

Berdasarkan hasil perhitungan terhadap 35 subjek pada laki-laki homoseksual terhadap pembentukan identitas orientasi seksual, terdapat empat faktor yang memiliki kontribusi. Keempat faktor tersebut adalah keluarga, pergaulan dan lingkungan, akhlak dan morak, serta pengetahuan agama yang lemah.

Berdasarkan hasil analisis diketahui bahwa dari keempat faktor tersebut, faktor yang memiliki kontribusi tertinggi dalam pembentukan identitas orientasi seksual pada homoseksual yang ada di cafe holliwings adalah faktor keluarga yaitu sebesar 27 persen. Lebih rinci lagi dijelaskan bahwa dari total 35 subjek sebanyak 7 orang berada pada kategori tinggi (20 persen), 18 orang berkategori sedang (51 persen), dan 10 orang berkategori rendah (29 persen). Menurut kartono pengalaman atau trauma di masa anak-anak menjadi salah satu penyebab timbulnya prilaku penyimpangan seksual ini, misalnya dikasari oleh ibu sehingga anak beranggapan semua pria bersikap kasar, dan bengis yang memungkinkan si anak merasa benci pada orang itu dalam (Kartono, 2009).

1. Faktor keluarga dapat menjadi faktor dominan dalam pembentukan identitas orientasi seksual terhadap homoseksual. Banyak dari mereka yang mengakui bahwa keluarga yang secara tidak langsung mendukung pembentukan identitas orientasi seksual menjadi homoseksual seperti ketika kecil di ibu sering memakaikan anak laki-lakinya aksesoris perempuan.

2. Faktor tertinggi kedua yang mempengaruhi pembentukan identitas orientasi seksual pada homosksual di cafe holliwings adalah faktor pergaulan dan lingkungan dengan persentase sebesar 26 persen. Lebih rincinya lagi di jelaskan bahwa sebanyak 8 orang berada pada kategori tinggi (23 persen), 22 orang berada pada kategori sedang (63 persen) dan sisanya sebanyak 5 orang berada 
pada kategori rendah (14 persen). Hal ini sesuai dengan pernyataan yang terdapat pada alat ukur yang dibagikan kepada 35 orang subjek penelitian, dari 9 aitem yang valid mengenai faktor lingkungan yang mendapat skor tertinggi yaitu 23 persen atau 8 orang subjek, dan pada sekor sedang yaitu 63 persen atau 22 orang yang menyatakan bahwa faktkor lingkungan dapat mempengaruhi pembentukan identitas orientasi seksual. Kemudian skor terendah 14 persen atau 5 orang subjek.

3. Faktor tertinggi ketiga yang mempengaruhi pembentukan identitas orientasi seksual pada homoseksual adalah faktor akhlak dan moral yaitu 6 orang (17 persen) di urutan terendah dalam mempengaruhi pembentukan identitas orientasi seksual. Kemudian sebanyak 21 orang (60 persen) berkontribusi sedang, dan sebanyak 8 orang (23 persen) menyatakan bahwa faktor akhlak dan moral berkontribusi tinggi dalam mempengaruhi pembentukan identitas orientasi seksual. Menurut kartono (2009) penyebabnya pengendalian hawa nafsu dan banyaknya rangsanngan seksual. Lemahnya iman juga dapat menyebabkan segala kejahatan terjadi, karena hanya keimanan yang mampu menjadi benteng paling efektif dalam mengekang penyimpangan seksual dalam (Kartono, 2009).

4. Faktor tertinggi keempat yang mempengaruhi pembentukan identitas orietasi seksual adalah faktor agama dengan persentase sebesar 22 persen. Lebih rinci lagi dijelaskan bahwa dalam faktor agama, dari 35 orang responden diketahui bahwa sebanyak 9 orang berada pada kategori tinggi (26 persen), sebanyak 19 orang berada pada kategori sedang (54 persen) dan sisanya sebanyak 7 orang berada pada kategori rendah (20 persen). Faktor agama menjadi hal yang sangat berpengaruh dalam hal pembentukan identitas orientasi seksual. Karena pentingnya agama dalam menentukan pilihan hidup. Menurut kartono (2009), Menurut elly Risma, Psi.,Kurangnya pemahaman agama atau agama Cuma di ajarkan sekedar numpang lewat: sebatas ritual tidak melalui penanaman nilai nilai dan prilaku merupakan peenyebab anak menjadi LGBT dalam (bangkapos.com).

Psikoanalisa Freud mengawali asumsinya tentang hukum kausalitas atau psychological determination. Teori ini menyatakan bahwa segala sebab pasti ada akibatnya dan segala akibat pasti ada sebabnya. Tidak ada suatu aktivitas yang dibuat oleh manusia kecuali ada sebab yang mendorongnya melakukan tindakan tersebut. Mungkin sebab itu nyata dan bisa jadi tidak nyata. Mungkin sebab itu logis dan bisa jadi tidak logis

\section{SIMPULAN}

Pada bab ini akan diuraikan simpulan dan saran-saran sehubungan dengan hasil yang diperoleh dari 
penelitian ini. Pada bagian pertama akan di jabarkan simpulan dari penelitian ini dan bagian berikutnya akan di kemukakan saran-saran yang mungkin dapar digunakan bagi pada pihak terkait. Berdasarkan hasil-hasil yang telah diperoleh dalam penelitian ini, maka dapat di simpulkan hal-hal sebagai berikut:

1. Dari keempat faktor yang mempengaruhi pembentukan identitas orientasi seksual terhadap homosensual faktor yang memiliki kontribusi besar adalah faktor keluarga dengan persentase sebesar 27 persen. Selanjutnya adalah faktor pergaulan dan lingkungan dengan persentase sebesar 26 persen. Yang ketiga adalah faktor akhlak dan moral dengan persentase sebesar 25 persen. Kemudian faktor agama adalah faktor terendah yang mempengaruhi pembentukan identitas orientasi seksual dalam penelitian ini dengan persentase sebesar 22 persen.

2. Dari 35 orang laki-laki hommoseksual yang diteliti, diketahui sebanyak 7 orang atau 20 persen menyatakan bahwa faktor keluarga mempengaruhi pembentukan identitas orientasi seksual. Sementara 10 orang atau 29 persen menyatakan bahwa faktor keluarga tidak mempengaruhi pembentukan identitas orientasi seksual. Dan selebihnya sebanyak 18 orang atau 51 persen memilih sedang.

3. Dari 35orang laki-laki homoseksual yang diteliti, diketahui sebanyak 8 orang atau 23 persen menyatakan bahwa faktor lingkungan mempengaruhi pembentukan identitas orientasi seksual. Sementara 5 orang atau 14 persen menyatakan bahwa faktor lingkungan tidak mempengaruhi pembentukan identitas orientasi seksual. Dan selebihnya sebanyak 22 orang atau 63 persen memilih sedang.

4. Dari 35 orang laki-laki homoseksual yang diteliti, diketahui sebanyak 8 orang atau 23 persen menyatakan bahwa faktorAkhlak dan moral mempengaruhi pembentukan identitas orientasi seksual. Sementara 6 orang atau 17 persen menyatakan bahwa faktor akhlak dan moral tidak mempengaruhi pembentukan identitas orientasi seksual. Dan selebihnya sebanyak 21 orang atau 60 persen memilih sedang.

5. Dari 35 orang laki-laki homoseksual yang diteliti, diketahui sebanyak 9 orang atau 26 persen menyatakan bahwa faktor lingkungan mempengaruhi pembentukan identitas orientasi seksual. Sementara 7 orang atau 20 persen menyatakan bahwa faktor lingkungan tidak mempengaruhi pembentukan identitas orientasi seksual. Dan selebihnya sebanyak 19 orang atau 54 persen memilih sedang.

\section{DAFTAR PUSTAKA}

Anggreini, Sekar. (2014). Kesejahteraan subjektif pria dengan orientasi seksual sejenis. Bandung: Universitas Pendidikan Indonesia. 
Braun \& Clarke. (2006). Using Thematic Analysis in Psychology. Qualitative Research in Pshycology, 3 (2). Pp 77-101. ISSN 1478-0887

Carroll, L. J. (2012). Sexuality Now: Embracing Diversity (4th ed.). USA: Belmont: Thomson Learning Inc.

Dermartoto, A. (2013). Seks, Gender, Sksualitas Gay dan Lesbian. Http://Argyo.Staff.Uns.Ac.Id/2013/04/24/Se ks-Genderseksualitas-Gay-Dan-Lesbian/.

Efa, Yuliwati. (2015). Identifikasi Orientasi Homoseksual Pada Laki-laki (gay) BerdasarkanTeori WHO.Skripsi thesis, Universitas Airlangga.

Fajriani, GAR. 2013. Gambaran social well being pada homoseksualdewasa muda yang melakukan coming out. Bandung. Universitas Pendidikan Indonesia.

Feldmen, R. S. (1990). Understanding Psychology, Second Edition. New York: McGraw-Hill Publishing Company.

Hadley, W. I., \& Erianjoni. (2019). Strategi Gay Dalam Mencari Pasangan Pertama Studi Kasus Lima Orang Mahasiswa Gay Di Kota Padang. Jurnal Perspektif.

Handayani, S (2013). Konsep Dan PrestasiDiri Gay Pada KelompokKegiatanSeni Di Kota Padang: UniversitasAndalas. Padang

Hawari, D. (2009). Pendekatanpsikoreligi pada homoseksual. Jakarta: Balai Penerbit FKUI.

Hurlock, E B. (2013). Child growth and development. USA: Literary Licensing; p.54Indryawati, Rini. (2006). Pengaruh pola asuh orang tua terhadap perilaku homoseksual. Jakarta: Universitas Gunadarma.

Irawan, A. . (2015). Aku Adalah Gay (Motif yang Melatarbelakangi Pilihan Sebagai Gay). Jurnal Bimbingan Dan Konseling.

Irawan, H. (2016). Faktor-Faktor Menjadi Gay.

Jinich, S., et al. (1998). Childhood sexual abuse and HIV risk-taking behavior among gay and bisexual men. AIDS and Behavior, 2(1), 41-51.

Kalat, J. (2007). Biological Psychology (9th ed). Thomson Wadsworth.

Kartono, K. (2009). No TitlePsikologi Abnormal dan Abnormallitas Seksual. Mandar Maju.

Mardiyah, Isyatul. (2017). Peran ayah dalam menanamkan sikap self acceptance dalam rangka mencegah perilaku homoseksual pada anak. Pontianak: Institusi Agama Islam Negeri (IAIN) Pontianak.

Noviana, I. (2015). Kekerasan seksual terhadap anak: dampak dan penanganannya. Jakarta:
Pusat Penelitian dan Pengembangan Kesejahteraan Sosial, Kementrian Sosial RI.

Oetomo, D. (2001). Member isuara pada yang Bisu. Yogyakarta: Galang Press.

Ott, M.A. (2010). Examining the development and sexual behavior of adolescent males. Journal of Adolescent Health, 46, S3-S11.

Papalia, D. E. (2008). Human Development (Psikologi Perkembangan).

Polusny, Melissa. A., \& Victoria, M. Folle. (1995). Long-term correlates of child sexual abuse: Theory and review of the empirical literature. USA: Applied \& Preventive Psychology 4:143-166.

Pontoh, Maria.M., dkk. (2015). Hubungan pola asuh orang tuadengan tingkat homoseksual pada komunitasgayx di Manado. Manado: Jurnal Biomedik (eBm), Volume 3.

Sadarjoen, S S. (2005). Bunga Rampai Kasus Psiko-Seksual (edisipertama). Bandung: PT RefikaAditama.

Santrock, John., W. (2003). Adolescence: perkembanganremaja (edisikeenam). (Penerj.Shinto B. Adelar, Sherly Saragih; Ed. Wisnu C, Kristiaji, YatiSumiharti). Jakarta: Erlangga.

Sarwono, S. W. (2009). Pengantar Psikologi Umum. PT RajaGrafindo Persada.

Sinyo. (2014). Anakkubertanyatentang LGBT. Jakarta: Gramedia.

Stuart, G.W. (2013). Principles and Practice of Psychiatric Nursing. Missouri: Elsevier Mosby.

Supratiknya. (1995). Mengenal Perilaku Abnormal. Kanisius.

Yustinus, Semiun. (2006). Kesehatan Mental 2. Yogyakarta: Kanisius.

Weber, Mark Reese., Smith, Dana M. (2010). Outcomes of Child Sexual Abuse as Predictors of laters Sexual Victimization. Journal of International Violence. (Online). 26 (9): 1899-1905. 